\title{
Implementation of Admission Guidelines in Colleges of Education in South East, Nigeria
}

\author{
Paul Chijioke Israel ${ }^{1}$, Happiness Cherechi Israel ${ }^{2}$ \\ ${ }^{1}$ Psychology Department, Federal College of Education, Obudu, Cross River State, Nigeria \\ ${ }^{2}$ Christian Religious Studies Department, Federal College of Education, Obudu, \\ Cross River State, Nigeria
}

\begin{abstract}
The regulation of entry qualification is one of the quality assurance measures in colleges of education. The essence of this measure is to ensure that only candidates with the mental capacity to pursue and complete a course of study in a tertiary institution are admitted into this level of education. The success of any policy measure toward the attainment of its underlying objectives however depends on the level of its implementation. Due to some unpleasant remarks about the quality of some products of teacher education institutions, this study was executed to determine the extent of implementation of some stipulated guidelines for the admission of students into colleges of education in the south East of Nigeria. In order to accomplish the study, the multistage sampling technique was used to draw six colleges out of eleven colleges of education in the area. From the six colleges, 205 academic and non academic staff were drawn out of about 2053 staff. The research data were collected using researchers' constructed Admission Guidelines Implementation Rating Scale (AGIRS). This instrument has a validity index of .95. It was supplemented by the Admission Guidelines Implementation Interview schedule also constructed by the researchers. The data so collected were analyzed by means of both descriptive and inferential statistics. The findings of the study showed that whereas some stipulated admission guidelines were being implemented to a high degree, the level of implementation of others were low. Also found was a disparity in the level of implementation of stipulated guidelines between federal colleges and privately owned colleges of education. Consequently, it was recommended that the National Commission for Colleges of Education (NCCE) should step up its monitoring and evaluation functions in the colleges with special attention given to the private colleges.
\end{abstract}

Keywords: education; level of education; National Commission; Nigeria

\section{INTRODUCTION}

Prior to the establishment of the National Commission for colleges of education in 1989 by the Federal Government of Nigeria, there was no common quality assurance mechanism for the colleges. Each college was affiliated to one university or another and with the aid of the affiliate university, each college had to set up its own academic standard, determined the admission and graduation requirements, and formulated its own policies regarding the monitoring and supervision of academic standards. The concomitant effect of this was a multiplicity of curricula with varying degrees of task difficulty and thus the absence of a 
common quality assurance mechanism as each of these institutions was concerned with satisfying the interest of its establishing body (Nwogwugwu, 1999).

In pursuit of harmony and common standard among these colleges, the Federal government of Nigeria in 1989 established the National Commission for Colleges of Education (NCCE) with the mandate to lay down minimum standards for all programmes of teacher education, accredit certificates and other academic awards after obtaining thereof prior approval of the Honourable Minister of education and approve guidelines setting out criteria for accreditation of all colleges of education (NCCE, 1991).

In response to this mandate, the NCCE in 1993 published what could be described as their quality manual for colleges of education by name "Guidelines for Academic Programmes". Prominent among the stipulated guidelines are those dealing with students entry requirement. The existence of a positive relationship between entry qualification and students performance [Ojaleye \& Ebeh, (2002), Royen, Dickon, Dickson, and Wells, (2006), and Ali, Gavino and Memon (2007)] makes mandatory the regulation of this quality measure. Such a regulation is required in order to secure a good match between the abilities and aptitude of applicants and the demands of the programme. Among the factors considered in the admission of students into tertiary institutions in Nigeria are age, number of papers passed at credit levels at school certificate or ordinary level examinations, catchment area, performance in the entrance examination e.t.c

Despite the above stipulations, there are reports of admission of unqualified candidates into our institutions of higher learning. For instance, Asuru (2002) investigated the implications of examination malpractice for sustainable development and came out with the submission that that poor admission policy/unqualified candidates who get admitted into our higher institutions were beneficiaries of examination malpractice. Asuru further remarks that the use of other considerations such as catchment area, educationally less developed states, university discretion coupled with endless list of PR (public relation) outside merit for admission impact negatively on our examinations.

Also, Ugwunga (cited in Onyishi, 2007) reported that in the 1998/99 academic session, $34.9 \%$ of total enrolment into colleges of education was in science, technology and mathematics and the related courses. This he says was contrary to policy stipulation of allocating not less than $60 \%$ of places to sciences and the related courses in the conventional schools. Similarly, Mohammed and Iyele (2001) attribute the poor quality in education in the country to poor quality of students admitted into teacher training institutions. Such remarks demand the investigation of the extent to which quality in teacher education is being assured through the effective implementation of admission regulations.

The question addressed by this study therefore is: What is the extent to which colleges of education in the South East of Nigeria offer admission to students based on the stipulated guidelines?

In order to establish the existence or otherwise of a difference in the level of policy implementation among the three categories of colleges of education, the study will also test at $5 \%$ level of significance the hypothesis that the three tiers of colleges of education in the south east do not differ significantly in their levels of implementation of admission guidelines.

\section{METHODOLOGY}

The design of the study was the descriptive survey research design. Kerlinger (1986) describes the survey research as a useful tool for educational fact-finding as we can learn a 
great deal about school system through sampling and without contacting every member of the population. This design was therefore considered appropriate because the study involved studying and describing the existing conditions in the area of implementation of quality assurance using the NCCE's guidelines as a yardstick. Also, in carrying out the investigation, only a representative sample of the population was studied instead of the entire population.

This study was carried out in the South sEast geo-political zone of the country. There are five states in this zone. These are: Abia, Anambra, Ebonyi, Enugu, and Imo. The population of the study consisted of approximately 2,053 academic and non-academic staff in the eleven colleges in the zone. About 1,453 members of the population are academic staff while 600 are Senior Administrative staff. Three of the colleges are federal colleges, 4 are state colleges and 4 are privately owned colleges. Five hundred and fifty three of the academic staff belong to the three federal colleges, 612 belong to the four state colleges whereas 288 belong to the four privately owned colleges (NCCE, 2007,2009). Similarly, 267, approximately 272, and 61 of the Senior Administrative staff belong to the federal, state, and privately owned colleges respectively.

The sample for the study comprised two hundred and five staff who must have served in their respective institutions for a minimum period of three years. This number was made up of 145 academic and 60 Senior Administrative staff. The academic staff included Directors of academic planning, Heads of Departments and Deans of schools. Also, the Senior Administrative staff included Registrars, Admission officers and Establishment officers.

The multi-stage sampling technique was used to constitute the sample. Using this method of sampling, the population was first stratified into three categories namely:- federal colleges, state colleges and private colleges of education respectively. Two colleges were then drawn from each of these strata using the disproportionate stratified random sampling technique. This resulted in the selection of a total of six colleges. At the next level of sampling, the proportionate stratified random sampling technique was used to draw 55, 60, and 30 academic staff from the federal, state, and private colleges respectively. These figures corresponded to an approximate ratio of 11:12:6 of the academic staff in these colleges. Similarly, 25, 25, and 10 Senior Administrative staff were drawn from the federal, state, and private colleges according to their non-academic staff ratio of approximately 5:5:1. The number drawn from the private colleges was however doubled in order to avoid a situation whereby the resultant number will not be sufficient for sampling the relevant units. The choice of Senior Administrative staff among the non-academic staff was informed by the fact that they are the group of non- academic staff that are acquainted with the issue under investigation i.e. students' admission/registration and hence, competent enough to supply reliable information.

The data required for this study were collected using mainly two different instruments constructed by the researchers. The instruments are the Admission Guidelines Implementation Rating Scale (AGIRS), and the Students Admission Interview Schedule (SAIS). Supplementary data were also collected through the analysis of some relevant documents. The AGIRS has 6 items. It was constructed by the researchers after a detailed review of literature and a thorough scrutiny of policy provisions in respect of admission into Nigerian colleges of education. It is a four-point rating scale designed to ascertain the extent of implementation. Weights of 1,2, 3, and 4 were assigned to the respective scale points in line with the indicated level of implementation. Admission officers and heads of departments were also interviewed to authenticate the information obtained with the rating scale whereas documentary analysis revealed the pattern of distribution of students according to schools (faculties).

The instruments were face validated by three experts in the Faculty of education University of Nigeria Nsukka and subsequently modified and trial tested at the Federal College 
of education Obudu. Using the Cronbach alpha formula, an internal reliability coefficient of .97 was established for the AGIRS.

The research data were collected by the researchers with the aid of five research assistants each of whom was sent to one college of education. The researchers also made personal appeals by phone calls to some of the respondents whose co-operation was difficult to secure by the research assistants. This was especially the case in the course of the interviews. Both the inferential and the descriptive statistics were used to analyze the data collected with the questionnaire. The research questions were answered using descriptive statistics of mean, standard deviation and simple percentage. Thus, any item with a computed mean of: $0.5-1.5$ was interpreted as very low extent; 1.5-2.5 was interpreted as low extent; 2.5-3.5 was interpreted as high extent; and 3.5-4.00 was interpreted as very high extent. However, in answering the research questions, the level of implementation by each category of colleges was determined by computing the aggregate mean score. On the other hand, the hypothesis was tested using the one way ANOVA.

\section{RESULT}

\section{1. Research Question}

What is the extent to which colleges of education in the South East of Nigeria offer admission to students based on the stipulated guidelines?

To answer this research question, the mean and standard deviation of each of the items of the research instrument were computed. The result is shown in Table 1.

Table 1. Mean and Standard Deviation of Rating Scores on Implementation of Admission Guidelines.

\begin{tabular}{|c|c|c|c|c|c|c|c|}
\hline \multirow{2}{*}{\multicolumn{2}{|c|}{ ITEMS }} & \multicolumn{3}{|c|}{ COLLEGES } & \multicolumn{3}{c|}{ REMARKS } \\
\cline { 2 - 9 } & $\begin{array}{c}\text { Federal } \\
(\mathrm{N}=52) \\
\mathrm{X} \text { SD }\end{array}$ & $\begin{array}{c}\text { State } \\
(\mathrm{N}=55) \\
\mathrm{X} \text { SD }\end{array}$ & $\begin{array}{c}\text { Private } \\
\text { (N }=20) \\
\mathrm{X} \text { SD }\end{array}$ & Fed. & State & Private \\
& $\begin{array}{c}\text { Attainment of } \\
\text { minimum age } \\
\text { of 16 years }\end{array}$ & $3.0,1.1$ & $3.0,1.1$ & $3.7,0.5$ & High & High & V. High \\
\hline 2. & $\begin{array}{c}\text { Admits through } \\
\text { UTME/Pre- } \\
\text { NCE }\end{array}$ & $3.6,0.6$ & $3.4,0.9$ & $3.2,10$ & V. High & High & High \\
\hline 3. & $\begin{array}{c}\text { Attainment of } \\
\text { cut-off point }\end{array}$ & $3.4,0.7$ & $3.0,1.1$ & $3.1,1.0$ & High & High & High \\
\hline 4. & $\begin{array}{c}\text { Adherence to } \\
\text { quota }\end{array}$ & $2.1,1.0$ & $2.0,1.0$ & $1.4,0.7$ & Low & Low & V. Low \\
\hline 5. & H.O.D's input & $1.7,0.7$ & $2.2,1.1$ & $2.2,0.9$ & Low & Low & Low \\
\hline 6. & $\begin{array}{c}\text { Consideration } \\
\text { of course of } \\
\text { study }\end{array}$ & $2.3,0.7$ & $2.5,1.1$ & $1.8,0.9$ & Low & High & Low \\
\hline
\end{tabular}

Aggregate: $\mathrm{N}=127$, Mean $=2.73, \mathrm{SD}=1.09$. Decision $=$ High extent.

Note: $\mathrm{X}=$ mean, $\mathrm{SD}=$ Standard deviation 
Table 1 shows that the federal, state and private colleges of education in the South East have mean rating scores of 3.0, 3.0, and 3.7 on the implementation of 16 years minimum age respectively. The federal colleges have a mean rating of 3.6, the state colleges have 3.4, and the private colleges have 3.2 on the requirement of admitting candidates through UTME/PreNCE. Also in the requirement of admitting only candidates who attained the cut-off point in the above examinations, the Federal colleges have a minimum rating of 3.4, the State colleges have 3.0, and the Private colleges have 3.1. Since these values are above 2.5 which is the lower limit for high extent, it means that each of the three categories of colleges adheres to a high extent to such admission requirement as attainment of minimum age of 16 years, admission of candidates through UTME (formerly MPCE) and Pre-NCE and insistence on attainment of cut of point by candidates. Also, the Table shows that the three tiers of colleges adhere to a low extent to such admission criteria as admission of students on the bases of different quotas for locality, merit, and educationally disadvantaged states as their mean rating scores on this criterion fall below the cut-off score of 2.5. The federal and private colleges with mean scores of 2.1 and 2.0 respectively adhere to a low extent to the requirement of different quotas for different courses. The state colleges on the other hand have a mean score of 2.5 on this criterion and therefore adhere to it to a high extent.

Since the cluster mean of 2.7 falls within the range of high extent (2.5-3.5) the colleges in the South East collectively implement to a high extent the admission guidelines irrespective of the above areas of weaknesses. Further analysis on the criterion of offering $60 \%$ of the admission places to science and science related courses is shown in Table 2.

Table 2. Distribution of 2011/2012 Entrants into the Three Categories of Colleges According to Schools.

\begin{tabular}{|c|c|c|c|c|c|c|}
\hline \multirow[b]{2}{*}{ SCHOOLS } & \multicolumn{2}{|c|}{ Federal colleges } & \multicolumn{2}{|c|}{ State colleges } & \multicolumn{2}{|c|}{ Private college } \\
\hline & $\underline{\mathrm{N}}$ & $\%$ & $\underline{\mathrm{N}}$ & $\%$ & $\underline{\mathrm{N}}$ & $\%$ \\
\hline Arts \& SOS & 73 & 4.73 & 683 & 46.34 & 50 & 42.74 \\
\hline Education & 169 & 10.95 & 85 & 5.77 & 7 & 5.98 \\
\hline Languages & 437 & 28.30 & 313 & 21.23 & 16 & 13.68 \\
\hline Science & 444 & 28.76 & 277 & 18. 79 & 26 & 22.22 \\
\hline Voced & 421 & 27.30 & 116 & 7.87 & 18 & 15.38 \\
\hline Total & 1,544 & 100 & 1,474 & 100 & 117 & 100 \\
\hline
\end{tabular}

Table 2 shows that out of a total of 1544 students admitted into the federal colleges in the 2011/2012 academic session, 444 representing $28.76 \%$ were admitted into the school of science. Also out of a total of 1474 admitted into the state colleges, only 277 representing 18.79 $\%$ were in the school of science. Similarly, out of 117 students admitted into the private colleges, only 26 representing $22.22 \%$ were admitted into the school of science. The number of students admitted into the school of science in the three tiers of colleges of education in the South East of Nigeria therefore falls short of the stipulated percentage. 


\section{Hypothesis:}

The three tiers of colleges of education in the South East Nigeria do not differ significantly $(\mathrm{P}<.05)$ in their levels of implementation of admission guidelines.

Table 3. One-Way Analysis of Variance of Mean Ratings of Federal, State and Private Colleges of Education on Implementation of Admission Guidelines.

\begin{tabular}{|c|c|c|c|c|c|}
\hline Source of variation & Sum of squares & Df & Mean square & F & Sig \\
\hline Between groups & 47.456 & 2 & 23.728 & & \\
\cline { 1 - 4 } Within groups & 750.009 & 124 & 6.048 & \multirow{2}{*}{3.923} & \multirow{2}{*}{022} \\
\hline Total & 797.465 & 126 & & & \\
\hline
\end{tabular}

Table 3 shows that the obtained $\mathrm{F}$ is significant at .022 probability level. It is therefore significant at .05 level of probability. This means that there is a significant difference in the level of implementation of admission guidelines among the three groups of colleges. The null hypothesis is therefore rejected. Further analysis of the source of this difference is shown in Table 4 below.

Table 4. Turkey HSD Multiple Comparison of Pairs of Means in Ratings on Students Admission.

\begin{tabular}{|c|c|c|c|c|}
\hline (I) Colleg type & (J) College type & Mean Difference (I-J) & Std. Error & Sig \\
\hline $\begin{array}{c}\text { Federal } \\
\text { colleges }\end{array}$ & $\begin{array}{c}\text { State colleges } \\
\text { Private colleges }\end{array}$ & $\begin{array}{c}.790 \\
1.758^{*}\end{array}$ & $\begin{array}{l}.476 \\
.647\end{array}$ & .225 \\
.020 \\
$\begin{array}{c}\text { State } \\
\text { colleges }\end{array}$ & $\begin{array}{c}\text { Federal colleges } \\
\text { Private colleges }\end{array}$ & $\begin{array}{c}-.790 \\
.968\end{array}$ & $\begin{array}{l}.476 \\
.642\end{array}$ & .225 \\
.291 \\
$\begin{array}{c}\text { Private } \\
\text { colleges }\end{array}$ & $\begin{array}{c}\text { Federal colleges } \\
\text { State colleges }\end{array}$ & $\begin{array}{c}-1.758^{*} \\
-.968\end{array}$ & $\begin{array}{c}.647 \\
.642\end{array}$ & .020 \\
.291 \\
\hline
\end{tabular}

* The mean difference is significant at .05 level

Table 4 shows a mean difference of 1.758 between the Federal and the Private colleges in their level of implementation of admission policy. This difference is significant at .020 probability level and as such at .05 level of probability. It implies that the Federal colleges differ significantly from the Private colleges in their implementation of admission guidelines. Since this difference is positive for Federal mean score minus Private mean score (I-J), it means that the Federal colleges perform better than the Private colleges in the implementation of admission policy. 


\section{DISCUSSION}

The findings of the study showed that colleges of education in the South East implement to a high extent those admission guidelines that deal with minimum age of students and attainment of cut-off score in either JAMB/UTME or Pre-NCE examination. On the other hand, a low level of implementation was established with those guidelines dealing with admission on quota basis and the involvement of Heads of Departments in the selection of candidates for admission.

All the three tiers of colleges were also found not to adhere to the consideration of different percentages to the science or arts related courses. This means that contrary to government's stipulation that science and science related courses should be given $60 \%$ of the admission offers, a much lower percentage is assigned to these courses. This finding is consistent with Ugwunga and Onyishi (2007). Both researchers reported $34.9 \%$ admission into colleges of education in 1998/99 for science courses and $44 \%$ into the universities in 1998 for science and science related courses respectively. This is against the stipulated $60 \%$. It was also found that the federal and private colleges do not consider courses of study while offering admission whereas the State colleges do. A possible explanation of this state of affairs is the fact that the state colleges are established to serve the interest of their owners in the area of manpower development. Hence, they are liable to consider course offering in line with the emphasis of their state governments. After all, the entire tune played by the piper is dictated by the person that pays him.

Considering the case of failure of the colleges to implement the quota system, it must be admitted that the inclusion of quota as a guideline in students' admission raises a moral question as to whether a qualified student should be denied admission simply because he is not from a given area/state. The varied answer this question is likely to elicit is another likely reason for the finding on the quota guideline.

A significant difference was found to exist between the federal and the private colleges. This difference which was to the credit of the federal colleges could be attributed to the fact that such colleges are better funded and are not established for profit motive like the private colleges and hence, are more likely to comply with the rules and regulations.

It was found in the course of this study that the guidelines for admission of students into the colleges of education are selectively implemented by the colleges in the South East and that the levels of implementation vary significantly among the different tiers of colleges. One implication of this is that the purpose of streamlining the programmes of these colleges for which the National Commission for Colleges of Education (NCCE) was set up were not being fully realized. Another implication of this finding is that while some colleges that decide to play down on some admission requirements may be enjoying a boom in students' population, others that insist on implementing the guidelines to the letters may be suffering from scanty students' enrolment. Where a boom in students' enrolment results in over-population, the problems of inadequacy of human resources and of infrastructure are bound to arise.

\section{CONCLUSION}

Colleges of education in the South East of Nigeria comply to a high extent with those admission guidelines that deal with minimum age and the attainment of cut-off score in either JAMB/UTME or Pre-NCE examination. However their level of compliance with requirements of quota system and that of offering $60 \%$ admission places to science and science related 
courses is found to be low. Worse still is the fact that the inputs of heads of departments are not sought before admitting students into their departments. This apparent imposition of students on heads of departments does not make for a healthy working relationship between the admission officer and the departmental heads. The level of implementation of admission guidelines is found to be higher in the federal colleges than in the private colleges.

\section{Recommendations}

Based on the findings of the study, the following recommendations are made:

1. The provost of every college of education should ensure that their admission officer works hand in hand with the Heads of Departments in the selection of candidates for admission.

2. The Quota system should be removed as a requirement for offering admission into colleges of education since the current low enrolment figures into these colleges makes its implementation difficult.

3. Preference should be given to school of science in the admission of students into colleges of education.

4. The NCCE should step up its monitoring and evaluation functions especially in the private colleges of education.

\section{References}

[1] Ali P. A., Gavino M. I. B., Memon A. A. (2007). Predictors of academic performance in the first year of nursing in Sindh Pakistan. Journal of Pakistan Medical Association 57 (4); 202-204.

[2] Asuru V. A. (2002). Examination malpractice: Implication for sustainable development in Nigeria. ECOJOTE ,1(1); 152-159.

[3] National Commission for colleges of education (1993). Guidelines on academic programme. Kaduna: Author

[4] National Commission for colleges of education (2007). Digest of statistics on colleges of education in Nigeria, 2003/2004 \& 2004/2005. Vol. 8. Kaduna: Author

[5] National Commission for colleges of education (2009). Digest of statistics on colleges of education and other NCE awarding institutions in Nigeira, 2005/06; 2006/07 \& 2007/08. vol. 9 No. 2. Kaduna: Author

[6] Ojaleye O., Ebeh C. (2002). An investigation of a decade of correlation study between the entry qualification grade and NCE final examination. The Nigerian Teacher Today $10(1) ; 88-95$.

[7] Onyishi B. O. (2007). Strategies for ensuring policy implementation on science, technology and mathematics education in Nigerian schools. Journal of Teacher Perspective, 1(3); 454-462. 
[8] Nwogwugwu P. C. (1999). Training teachers for the sciences in Nigerian colleges of education: Issues and possible solutions. In Adegoke, R; Oduwaiye, J.O.M; Adeniji, B.A; and Aniodo,D.A (Eds.) Issues in the Challenges of Science Teaching in the $21^{\text {st }}$ Century (pp. 47-53). Abeokute: School of Science, Federal College of Education Abeokute.

[9] Kerlinger F. N. (1986). Foundations of behavioural research (3 ${ }^{\text {rd }}$ ed.) New York : CBS Publishing.

[10] Royen R., Dickon A., Dickson G., Wells C. (2006). Entry criteria as predictor of performance in an undergraduate nursing degree programme. Retrieved November 25, 2008 from www.nibi.NM.nih.gov/pubmed/16624454

[11] Abdulrahaman W. Lawal, International Letters of Social and Humanistic Sciences 3 (2014) 53-59.

[12] Alaba E. Dare, International Letters of Social and Humanistic Sciences 3 (2014) 73-79.

[13] Grema Maina Bukar, Yohanna A. Timothy, International Letters of Social and Humanistic Sciences 4 (2014) 9-21.

[14] Akor Isaiah Akem, Victor Tavershima Ukeli, International Letters of Social and Humanistic Sciences 4 (2014) 49-59.

[15] Sule Maina, International Letters of Social and Humanistic Sciences 4 (2014) 87-96.

[16] Odo John Ogar, International Letters of Social and Humanistic Sciences 8(1) (2014) 2 8-33.

[17] Elizabeth Morenikeji Titilayo Adediran, Albert Oluyomi Kehinde, International Letters of Social and Humanistic Sciences 8(1) (2014) 66-75.

[18] S. A. Kazeem, K. Y. Balogun, International Letters of Social and Humanistic Sciences 8(2) (2014) 108-119.

[19] Sanusi L. Sa'adatu, International Letters of Social and Humanistic Sciences 8(2) (2014) $140-147$.

[20] Rowland U. Aleshi, Clementina N. Iloh, International Letters of Social and Humanistic Sciences 8(3) (2014) 208-216

[21] Hannatu Abdullahi, International Letters of Social and Humanistic Sciences 8(3) (2014) 217-223.

[22] Fowoyo Joseph Taiwo, International Letters of Social and Humanistic Sciences 8(3) (2014) 244-251. 